\title{
Radiation Effects on Growth Are Altered in Rats by Prednisolone and Methotrexate
}

\author{
ANN SCHUNIOR, PHYLLIS J. MULLENIX, ANNA E. ZENGEL, HAL LANDY, ANTHONY HOWES, \\ AND NANCY J. TARBELL \\ Department of Toxicology, Forsyth Research Institute [A.S., P.J.M., A.E.Z.]; Department of Radiation Oncology, \\ Joint Center for Radiation Therapy, Harvard Medical School [P.J.M., A.H., N.J.T.]; and Department of \\ Endocrinology, Children's Hospital Medical Center [H.L.], Boston, Massachusetts 02115
}

\begin{abstract}
CNS therapy for childhood leukemia has adverse effects upon growth and cognition. The cause of these deficits is unknown. In a rat model, we determined which agent, or combination of agents, in CNS therapy affected growth. Young Sprague-Dawley rats were exposed to cranial irradiation (1000 cGy), methotrexate ( 2 or $4 \mathrm{mg}$ / kg, intraperitoneally), or prednisolone $(18$ or $36 \mathrm{mg} / \mathrm{kg}$, intraperitoneally) alone or in two- or three-agent combinations. Matched control groups received appropriate sham radiation, intraperitoneal saline, or both. Body weight was recorded from 14 through $150 \mathrm{~d}$ of age. After the rats were killed at $150 \mathrm{~d}$, body length was recorded and the head and left femur were removed to determine body and craniofacial proportions. Cranial irradiation alone, but not methotrexate or prednisolone alone, stunted growth permanently and altered craniofacial proportions. When these agents were combined, methotrexate and prednisolone modified the growth response to cranial irradiation. Methotrexate given before cranial irradiation prevented radiation stunting in males. This protection was lost when the dose of methotrexate was increased, when prednisolone was added to the combination, or when females were studied. The protection in males was effective against both growth and behavioral deficits. These results indicate that the physical and behavioral side effects of CNS therapy are better understood in the context of dose, sex, and interactions of the agents. (Pediatr Res 35: 416-423, 1994)
\end{abstract}

\section{Abbreviations}

ALL, acute lymphoblastic leukemia

i.p., intraperitoneal(ly)

P, treatment with prednisolone

GRF, growth hormone-releasing factor

$M$, treatment with methotrexate

$X$, treatment with cranial irradiation

CNS therapy for childhood ALL has well-documented adverse effects on growth and cognition. The growth deficits include short stature, increased weight for height, microcephaly, midfacial hypoplasia, and mandibular retrognathia (1-5). The cognitive deficits do not include mental retardation or hyperactivity, but significant reductions in overall IQ scores develop, along with impaired verbal and visual-spatial memory abilities, attention, organization, and motor output (6-8).

Received April 26, 1993; accepted November 10, 1993.

Correspondence and reprint requests: Dr. Phyllis Mullenix, Department of Toxicology, Forsyth Research Institute, 140 Fenway, Boston, MA 02115.

Supported by NIH CA53858.
The cause of these adverse effects has been reported to be cranial irradiation alone (9-11), or cranial irradiation interacting with chemotherapy $(1,4,12)$. Cranial irradiation or methotrexate has been manipulated in CNS therapy in an attempt to prevent neurotoxic interactions (13-15). Yet, the impact of these manipulations is uncertain, considering that some cranial irradiation and methotrexate interactions may be protective rather than neurotoxic. Balsom et al. (16) found that preirradiation methotrexate protected against decreased intellectual function in ALL survivors, illustrating the importance of agent interactions and sequence of administration to long-term outcome.

We developed an animal model to study growth and behavioral deficits associated with exposures to cranial irradiation, methotrexate, and prednisolone, either as single agents or as combinations $(17,18)$. Cranial irradiation alone stunted growth without significantly altering behavior, whereas cranial irradiation combined with methotrexate and prednisolone disrupted behavior in addition to stunting growth. Further study of behavior (19) demonstrated how different agent interactions affected outcome: 1) behavioral "signatures" varied with the components of the agent combinations; 2) behavioral outcome was influenced by steroids as well as by cranial irradiation and methotrexate; 3) behavioral outcome was sex dependent; and 4) behavioral outcome varied with dose, which determined whether agents interacted antagonistically or synergistically. Therefore, not all agent

Table 1. Exposure groups

\begin{tabular}{|c|c|}
\hline Exposure* & Abbreviation \\
\hline Prednisolone $-18 \mathrm{mg} / \mathrm{kg}$ & $P_{18}$ \\
\hline Prednisolone $-36 \mathrm{mg} / \mathrm{kg}$ & $P_{36}$ \\
\hline Methotrexate $-2 \mathrm{mg} / \mathrm{kg}$ & $\mathrm{M}_{2}$ \\
\hline Methotrexate-4 mg/kg & $\mathrm{M}_{4}$ \\
\hline Cranial irradiation $-1000 \mathrm{cGy}$ & $x+$ \\
\hline $\begin{array}{l}\text { Prednisolone }-18 \mathrm{mg} / \mathrm{kg}+ \\
\text { methotrexate }-2 \mathrm{mg} / \mathrm{kg}\end{array}$ & $\mathrm{P}_{18} \mathrm{M}_{2}$ \\
\hline $\begin{array}{l}\text { Prednisolone }-36 \mathrm{mg} / \mathrm{kg}+ \\
\text { methotrexate }-4 \mathrm{mg} / \mathrm{kg}\end{array}$ & $\mathrm{P}_{36} \mathrm{M}_{4}$ \\
\hline $\begin{array}{l}\text { Methotrexate }-2 \mathrm{mg} / \mathrm{kg}+\text { cranial } \\
\text { irradiation }-1000 \mathrm{cGy}\end{array}$ & $M_{2} X$ \\
\hline $\begin{array}{l}\text { Methotrexate }-4 \mathrm{mg} / \mathrm{kg}+\text { cranial } \\
\text { irradiation }-1000 \mathrm{cGy}\end{array}$ & $\mathbf{M}_{4} \mathbf{X}$ \\
\hline $\begin{array}{l}\text { Prednisolone }-18 \mathrm{mg} / \mathrm{kg}+ \\
\text { cranial irradiation }-1000 \mathrm{cGy}\end{array}$ & $P_{18} X$ \\
\hline $\begin{array}{l}\text { Prednisolone }-18 \mathrm{mg} / \mathrm{kg}+ \\
\text { methotrexate }-2 \mathrm{mg} / \mathrm{kg}+ \\
\text { cranial irradiation }-1000 \mathrm{cGy}\end{array}$ & $\mathrm{P}_{18} \mathrm{M}_{2} \mathrm{X} \dagger$ \\
\hline
\end{tabular}

* Each exposure had a corresponding control group.

$\dagger$ Exposure and matched control groups from Schunior et al. (18). 

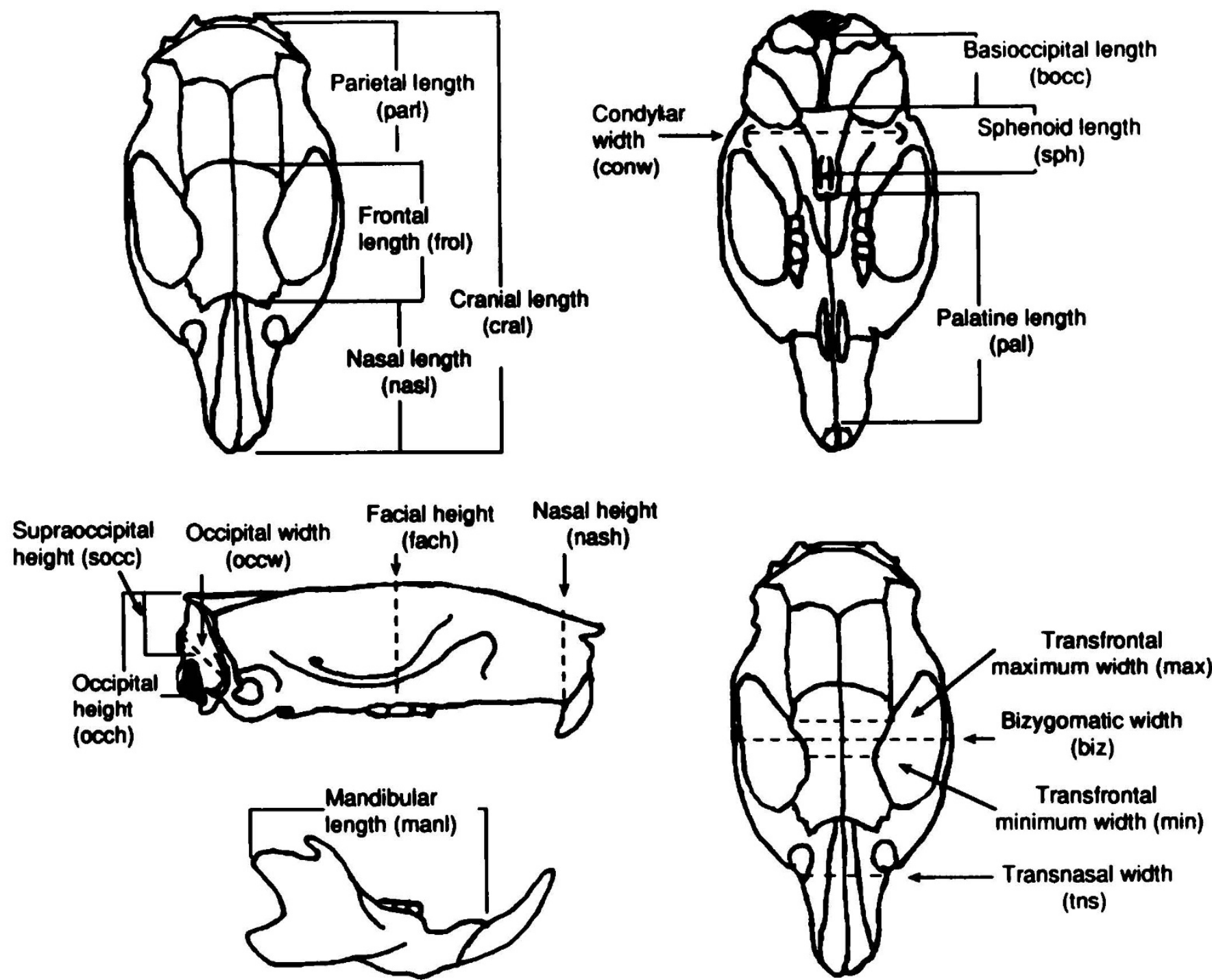

Fig. 1. Skull measurements. See Table 2 and Schunior et al. (18) for definitions of dimensions.

interactions disrupted behavior; certain combinations actually minimized behavioral deficits.

A systematic study of CNS therapy combinations that minimize neurotoxicity (growth and behavioral deficits) has not been attempted. Effects on growth and behavior have been linked in brain lesion studies in rats, where the anatomical substrate for generalized learning impairment has been shown to overlap with that of a set point for body size (20). In a study of childhood survivors of ALL, it was suggested that only children with reduced head circumference developed neuropsychologic complications (21). If behavioral deficits and stunted head growth were directly related, cranial irradiation would alter behavior whenever it stunted head size. Our prior studies of cranial irradiation in rats indicated that such a direct relationship does not occur $(17,18)$

The present study explores the growth-behavior relationship in response to various CNS therapy combinations. Using the same animal model as in our behavioral studies (19), we determined whether the combinations affecting behavior also affect growth and whether sex- or dose-dependency, antagonism, or synergism influence growth as they do behavior. If the two coincide, optimal combinations that minimize both the physical and neuropsychologic deficits of CNS therapy might be possible.

\section{MATERIALS AND METHODS}

Male and female 9-d-old (day of birth $=0$ ) pathogen-free Sprague-Dawley rats were shipped with dams from the Charles
River Laboratories (Kingston, RI), then housed 10 pups per dam. Specified nonlittermates, each sex was assigned randomly to either an experimental group or its matched controls. The rats were maintained on certified Purina Rat Chow (No. 5002, Ralston-Purina, St. Louis, MO) and tap water ad libitum. Light cycles were set as 12-h light $(0600$ to $1800 \mathrm{~h})$ /dark periods. All procedures involving animals were conducted under the auspices of Forsyth's Institutional Animal Care and Use Committee.

The experimental groups are listed in Table 1. The groups treated with prednisolone (prednisolone sodium succinate in saline; Sigma Chemical Co., St. Louis, MO) received i.p. injections on postnatal d 17 and 18 . Those treated with methotrexate [(+) amethopterin in saline; Sigma] received i.p. injections on d 18 only. When experimental groups received more than one treatment on d 18, the sequence of administration was always prednisolone first, methotrexate second, and cranial irradiation last, 1-3 $\mathrm{h}$ after injections. The doses of all three agents were selected to be clinically relevant and to avoid lethality or obvious neurotoxicity (18). Controls received sham i.p. injections of an equal volume/body weight of saline on $d 17, d 18$, or both to match each experimental group.

The experimental groups receiving cranial irradiation were exposed on d 18 between 0900 and $1200 \mathrm{~h}$ using previously described procedures (18). Rats were immobilized with pentobarbital anesthesia $(25 \mathrm{mg} / \mathrm{kg}$, i.p.). They were exposed six to eight at a time to a lateral beam of $x$-rays produced by a Phillips 
Table 2. Modified measures

\begin{tabular}{|c|c|}
\hline Measurement & Definition \\
\hline Femoral width & $\begin{array}{l}\text { Medial-lateral diameter just distal to the } \\
\text { lateral tuberocity }\end{array}$ \\
\hline Cranial length & $\begin{array}{l}\text { Midline distance from anterior tip of nasal } \\
\text { bone to the most posterior point of the } \\
\text { interparietal/supraoccipital suture }\end{array}$ \\
\hline Parietal length & $\begin{array}{l}\text { Midline distance from frontal/parietal su- } \\
\text { ture to interparietal/supraoccipital su- } \\
\text { ture; includes the length of the parietal } \\
\text { and intraparietal bones }\end{array}$ \\
\hline Supraoccipital height & $\begin{array}{l}\text { Midline distance from interparietal/su- } \\
\text { praoccipital suture to most dorsal apex of } \\
\text { foramen magnum }\end{array}$ \\
\hline Basioccipital length & $\begin{array}{l}\text { Midline distance from ventral aspect of the } \\
\text { foramen magnum to the basioccipital/ } \\
\text { sphenoid suture }\end{array}$ \\
\hline Sphenoid length & $\begin{array}{l}\text { Midline distance from the basioccipital/ } \\
\text { sphenoid suture to the sphenoid/pre- } \\
\text { sphenoid suture }\end{array}$ \\
\hline Palatine length & $\begin{array}{l}\text { Midline distance from the most posterior } \\
\text { point on the palatine bone to the incisive } \\
\text { foramen }\end{array}$ \\
\hline Occipital width & $\begin{array}{l}\text { Widest transverse distance across supraoc- } \\
\text { cipital bone including lateral sutures } \\
\text { above the foramen magnum }\end{array}$ \\
\hline Condylar width & $\begin{array}{l}\text { Transverse distance between midpoints of } \\
\text { condylar fossae }\end{array}$ \\
\hline
\end{tabular}

Table 3. Overall growth effects of CNS therapy exposure groups*

\begin{tabular}{lccccccccccc}
\hline Exposure & $\mathrm{P}_{18}$ & $\mathrm{P}_{36}$ & $\mathrm{M}_{2}$ & $\mathrm{M}_{4}$ & $\mathrm{X}$ & $\mathrm{P}_{18} \mathrm{M}_{2}$ & $\mathrm{P}_{36} \mathrm{M}_{4}$ & $\mathrm{P}_{18} \mathrm{X}$ & $\mathrm{M}_{2} \mathrm{X}$ & $\mathrm{M}_{4} \mathrm{X}$ & $\mathrm{P}_{18} \mathrm{M}_{2} \mathrm{X}$ \\
\hline Females & 6 & 0 & 0 & 1 & 22 & 0 & 9 & 21 & 22 & 20 & 28 \\
Males & 0 & 0 & 3 & 0 & 28 & 0 & 8 & 16 & 7 & 24 & 27 \\
\hline
\end{tabular}

* The number of significant changes $(p<0.01, t$ test or MannWhitney) among a total of 43 experimental-control comparisons. The 43 include body weight and length, femoral width and length, 18 craniofacial measures, and 21 body and cranial proportions.

$\mathrm{x}$-ray machine operating at $250 \mathrm{kV}$ peaks with 0.35 -mm copper filtration. Each animal was shielded with 2-mm-thick lead placed over the body and face. The eyes, oropharyngeal mucosa, and salivary tissues were protected while the skull from behind the eyes to the midposterior neck was exposed. The calculated midbrain dose rate was $125 \mathrm{cGy} / \mathrm{min}$; each irradiated brain received a total of $1000 \mathrm{cGy} \pm 5 \%$ in a single fraction over $8 \mathrm{~min}$. This dose approximated a biologic equivalent to the clinical dose of

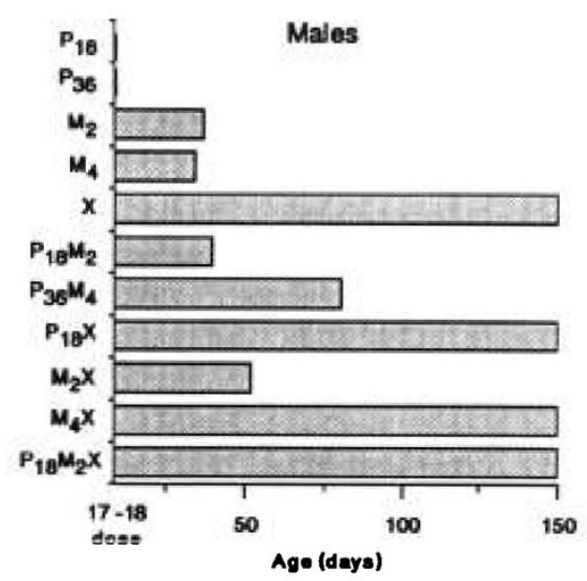

2400 cGy given in 12-14 fractions (18). After pentobarbital anesthesia, control animals were sham-irradiated by similar placement in the radiation beam but with complete shielding by 6-mm-thick lead.

On d 21, all pups were weaned and housed by treatment two per cage per sex. Individual body weight was recorded in 13-24 rats per treatment per sex, three times weekly from 14 to $120 \mathrm{~d}$ of age and weekly from 120 to $150 \mathrm{~d}$ of age. Rats $150 \mathrm{~d}$ old were asphyxiated with $\mathrm{CO}_{2}$ and then weighed. Body length was measured from tip of snout to base of tail. The head and left femur were removed and defleshed in a beetle colony (Dermestes vulpinus) as previously described (18). Eighteen craniofacial measurements (Fig. 1) and femoral width and length measurements were performed on at least 10 rats per sex for each exposure group and their matching controls. These measures have been previously defined (18), except for the modifications described in Table 2: facial and calvarial lengths were replaced with separate measures of the nasal, frontal, and parietal bone lengths; cranial length was redefined to include the entire dorsal surface; and measures revealing ventral and posterior aspects of the skulls were added (basioccipital, sphenoid, and palatine lengths, supraoccipital height, and occipital width). Each cranial measure was divided by cranial length to determine craniofacial proportions. In addition, body proportions were determined from the ratios body length/body weight, cranial length/body length, femur length/body length, and femur width/femur length. In all, a total of $\mathbf{4 3}$ growth parameters were considered for each exposure group and its matched control. To determine statistical significance, a $t$ test was used for body and cranial measures and body proportions, and the Mann-Whitney test was used for cranial proportions. Statistical significance was set at the $p<0.01$ level.

Growth evaluations were conducted on the animals described in a concurrent study of behavior (19). Spontaneous behavior was tested at 42 and $120 \mathrm{~d}$ of age using a computer pattern recognition system that monitored behavioral acts during a 15min exploration of a novel environment. The computer identified multiple behavioral acts and quantified their initiations, total times, and time structures for each exposure group and its matched control.

\section{RESULTS}

With the exception of the $\mathrm{M}_{2} \mathrm{X}$ combination in males, all treatments involving cranial irradiation $\left(X, M_{2} X, M_{4} X, P_{18} X\right.$, and $P_{18} \mathrm{M}_{2} \mathrm{X}$ ) permanently stunted growth. In Table 3 the overall growth effects are totaled for each exposure group, and the time of significant body weight reduction posttreatment for each exposure group is illustrated in Figure 2. Mortality did not

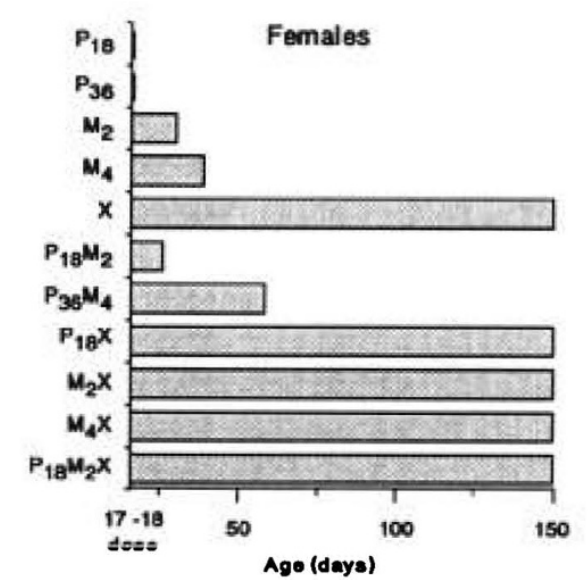

Fig. 2. Time to recovery of normal weight after exposure. Shaded bars represent days when body weights of treated rats were significantly different from matched controls. Bars extending to $150 \mathrm{~d}$ indicate a permanent reduction in weight. 


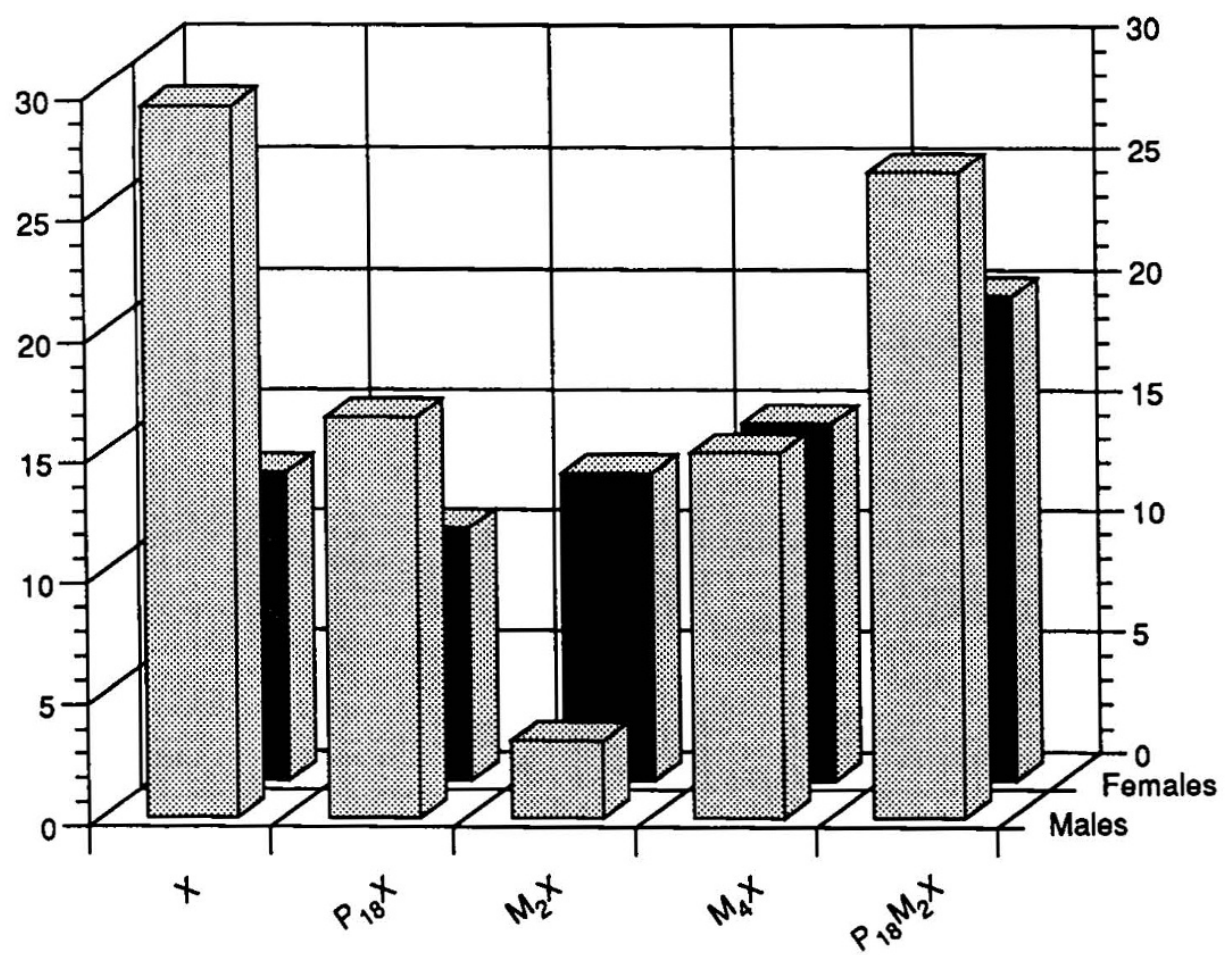

Fig. 3. Percent body weight reduction in $\mathrm{X}$ exposure groups compared with matched controls at $150 \mathrm{~d}$ of age. Reductions greater that $5 \%$ are statistically significant. Note that significant reductions occurred in all irradiated groups except the $\mathbf{M}_{\mathbf{2}} \mathrm{X}$ males.

Table 4. Changes in body and craniofacial proportions*

\begin{tabular}{|c|c|c|c|c|c|c|c|c|c|c|}
\hline & \multicolumn{10}{|c|}{ Exposure } \\
\hline & \multicolumn{5}{|c|}{ Females } & \multicolumn{5}{|c|}{ Males } \\
\hline & $\mathrm{x}$ & $P_{18} X$ & $\mathrm{M}_{2} \mathrm{X}$ & $\mathrm{M}_{4} \mathrm{X}$ & $\mathrm{P}_{18} \mathrm{M}_{2} \mathrm{X}$ & $\mathrm{X}$ & $P_{18} X$ & $\mathrm{M}_{2} \mathrm{X}$ & $\mathrm{M}_{4} \mathrm{X}$ & $\mathrm{P}_{18} \mathrm{M}_{2} \mathrm{X}$ \\
\hline \multicolumn{11}{|l|}{ Body proportions } \\
\hline Body length/wt & & & + & & + & + & + & & + & + \\
\hline Feml/body length & + & & & & + & + & & & & \\
\hline Femw/feml & & & & & & & + & & & \\
\hline Cral/body length & & & & & & + & & & & \\
\hline \multicolumn{11}{|l|}{ Cranial proportions } \\
\hline $\mathrm{Nasl} / \mathrm{cral}$ & + & & + & & + & & + & & & \\
\hline $\begin{array}{l}\text { Frol/cral } \\
\text { Parl/cral }\end{array}$ & & + & & & & & & & & \\
\hline $\begin{array}{l}\mathrm{Parl} / \mathrm{cral} \\
\mathrm{Pal} / \mathrm{cral}\end{array}$ & & $\begin{array}{l}+ \\
+\end{array}$ & & & & & & & & \\
\hline Bocc/cral & + & & + & & + & + & & & & + \\
\hline Sph/cral & + & + & & + & + & & & & & + \\
\hline Socc/cral & + & + & + & + & + & + & + & & + & + \\
\hline Occh/cral & + & + & + & + & + & + & + & & + & \\
\hline Occw/cral & + & & & & + & & & & & \\
\hline Fach/cral & & & & & & & & & & \\
\hline Nash/cral & & & & & + & & & & & \\
\hline $\mathrm{Biz} / \mathrm{cral}$ & & & & & + & + & & & & + \\
\hline Tns/cral & & & & & & & & & & \\
\hline $\mathrm{Max} / \mathrm{cral}$ & & & & & & & & & & + \\
\hline Min/cral & + & & & & + & & & & & \\
\hline Conw/cral & & & & & & & & & & \\
\hline Manl/cral & & & & & & + & & & & \\
\hline
\end{tabular}

- + Signifies change from control value ( $p \leq 0.01, t$ test or Mann-Whitney). Feml, femoral length; Femw, femoral width; Cral, cranial length; Nasl, nasal length; Frol, frontal length; Parl, parietal length; Pal, palatine length; Bocc, basioccipital length; Sph, sphenoid length; Socc, supraoccipital height; Occh, occipital height; Occw, occipital width; Fach, facial height; Nash, nasal height; Biz, bizygomatic width; Tns, transnasal width; Max, transfrontal maximum width; Min, transfrontal minimum width; Conw, condylar width; Manl, mandibular length.

confound the growth effects of radiation; treatment-related death occurred only in three animals exposed to $\mathrm{P}_{36} \mathrm{M}_{4}$. Exposures without cranial irradiation $\left(\mathbf{P}_{18}, \mathbf{P}_{36}, \mathbf{M}_{2}, \mathbf{M}_{4}, \mathbf{P}_{18} \mathbf{M}_{2}\right.$, and $\left.\mathbf{P}_{36} \mathbf{M}_{4}\right)$ did not permanently reduce body weight, shorten length, alter body proportions, or distort craniofacial proportions in any consistent pattern. In fact, neither dose of prednisolone $\left(\mathrm{P}_{18}\right.$ or $\left.P_{36}\right)$ retarded body weight at any time. Methotrexate, alone $\left(\mathbf{M}_{2}\right.$ and $\left.\mathbf{M}_{4}\right)$ or combined with prednisolone $\left(\mathbf{P}_{18} \mathbf{M}_{2}\right.$ and $\left.\mathbf{P}_{36} \mathbf{M}_{4}\right)$, 
Table 5. Body proportions

\begin{tabular}{|c|c|c|c|c|c|c|c|c|}
\hline \multirow[b]{2}{*}{ Exposure } & \multicolumn{2}{|c|}{ Body weight (g) } & \multicolumn{2}{|c|}{ Body length (mm) } & \multicolumn{2}{|c|}{ Body length/weight } & \multicolumn{2}{|c|}{ Cranial length/body length } \\
\hline & Control & Exposed & Control & Exposed & Control & Exposed & Control & Exposed \\
\hline \multicolumn{9}{|l|}{ Females } \\
\hline $\mathrm{X}^{*}$ & $331.5 \pm 38.8$ & $297.4 \pm 18.1 \dagger$ & $228.5 \pm 4.6$ & $215.7 \pm 4.4 \ddagger$ & $0.688 \pm 0.047$ & $0.728 \pm 0.041 \S$ & $0.206 \pm 0.004$ & $0.209 \pm 0.003 \S$ \\
\hline$n$ & 19 & 20 & 14 & 14 & 14 & 14 & 14 & 14 \\
\hline$P_{18} X$ & $379.0 \pm 29.7$ & $339.9 \pm 39.9 \dagger$ & $219.3 \pm 6.8$ & $210.2 \pm 7.2 \|$ & $0.590 \pm 0.042$ & $0.614 \pm 0.064$ & $0.219 \pm 0.004$ & $0.218 \pm 0.009$ \\
\hline$n$ & 23 & 21 & 13 & 12 & 13 & 12 & 13 & 12 \\
\hline $\mathbf{M}_{2} \mathbf{X}$ & $354.8 \pm 28.9$ & $314.6 \pm 35.9 \dagger$ & $214.4 \pm 5.0$ & $207.1 \pm 6.4 \|$ & $0.614 \pm 0.029$ & $0.665 \pm 0.059 \|$ & $0.219 \pm 0.005$ & $0.218 \pm 0.006$ \\
\hline$n$ & 24 & 21 & 15 & 13 & 15 & 13 & 15 & 13 \\
\hline$M_{4} X$ & $378.7 \pm 39.9$ & $324.1 \pm 40.2 \ddagger$ & $218.6 \pm 5.1$ & $208.8 \pm 5.5 \ddagger$ & $0.576 \pm 0.046$ & $0.619 \pm 0.064$ & $0.217 \pm 0.004$ & $0.219 \pm 0.007$ \\
\hline$n$ & 23 & 23 & 14 & 13 & 14 & 13 & 14 & 13 \\
\hline $\mathrm{P}_{18} \mathrm{M}_{2} \mathrm{X}^{*}$ & $313.9 \pm 25.2$ & $249.9 \pm 25.4 \ddagger$ & $221.4 \pm 6.1$ & $205.8 \pm 8.1 \ddagger$ & $0.708 \pm 0.041$ & $0.830 \pm 0.078 \ddagger$ & $0.207 \pm 0.005$ & $0.211 \pm 0.008$ \\
\hline$n$ & 18 & 19 & 17 & 19 & 17 & 19 & 16 & 19 \\
\hline \multicolumn{9}{|l|}{ Males } \\
\hline $\begin{array}{l}\mathrm{X}^{*} \\
n\end{array}$ & $\begin{array}{c}612.8 \pm 50.3 \\
20\end{array}$ & $\begin{array}{c}427.6 \pm 62.9 \ddagger \\
17\end{array}$ & $\begin{array}{c}267.2 \pm 6.5 \\
13\end{array}$ & $\begin{array}{c}237.7 \pm 9.7 \ddagger \\
11\end{array}$ & $\begin{array}{c}0.444 \pm 0.031 \\
13\end{array}$ & $\begin{array}{c}0.576 \pm 0.056 \ddagger \\
11\end{array}$ & $\begin{array}{c}0.190 \pm 0.003 \\
12\end{array}$ & $\begin{array}{c}0.199 \pm 0.005 \ddagger \\
10\end{array}$ \\
\hline$P_{18} X$ & $692.3 \pm 80.4$ & $574.5 \pm 99.3 \ddagger$ & $244.2 \pm 5.2$ & $239.4 \pm 6.5$ & $0.352 \pm 0.035$ & $0.401 \pm 0.050 \S$ & $0.210 \pm 0.005$ & $0.207 \pm 0.004$ \\
\hline & 21 & 22 & 12 & 12 & 12 & 12 & 12 & 12 \\
\hline $\mathrm{M}_{2} \mathrm{X}$ & $602.1 \pm 49.7$ & $576.4 \pm 83.4$ & $242.0 \pm 8.3$ & $238.4 \pm 11.3$ & $0.409 \pm 0.033$ & $0.419 \pm 0.051$ & $0.210 \pm 0.007$ & $0.207 \pm 0.005$ \\
\hline$n$ & 21 & 25 & 13 & 17 & 13 & 17 & 13 & 17 \\
\hline$M_{4} X$ & $666.7 \pm 66.0$ & $571.8 \pm 103.9 \dagger$ & $248.8 \pm 6.5$ & $234.6 \pm 10.2 \dagger$ & $0.361 \pm 0.027$ & $0.426 \pm 0.059 \|$ & $0.206 \pm 0.007$ & $0.207 \pm 0.006$ \\
\hline$n$ & 21 & 21 & 12 & 12 & 12 & 12 & 12 & 12 \\
\hline $\mathrm{P}_{18} \mathrm{M}_{2} \mathrm{X}^{*}$ & $629.8 \pm 77.0$ & $454.8 \pm 73.2 \ddagger$ & $261.5 \pm 6.4$ & $235.1 \pm 8.2 \ddagger$ & $0.420 \pm 0.045$ & $0.513 \pm 0.059 \dagger$ & $0.190 \pm 0.006$ & $0.194 \pm 0.005$ \\
\hline$n$ & 13 & 13 & 13 & 11 & 13 & 11 & 13 & 11 \\
\hline
\end{tabular}

* Data originally presented in Schunior et al. (18).

$\dagger p \leq 0.001 ; t$ test.

$\ddagger p \leq 0.0001 ; t$ test.

$\S p \leq 0.05 ; t$ test (not considered statistically significant).

$\| p \leq 0.01 ; t$ test.

Table 6. Craniofacial proportions

\begin{tabular}{|c|c|c|c|c|c|c|}
\hline \multirow[b]{2}{*}{ Exposure } & \multicolumn{2}{|c|}{ Basioccipital/cranial length } & \multicolumn{2}{|c|}{ Sphenoid/cranial length } & \multicolumn{2}{|c|}{ Supraoccipital/cranial length } \\
\hline & Control & Exposed & Control & Exposed & Control & Exposed \\
\hline \multicolumn{7}{|l|}{ Females } \\
\hline $\mathrm{X}$ & $0.150 \pm 0.003$ & $0.140 \pm 0.005^{*}$ & $0.173 \pm 0.006$ & $0.163 \pm 0.006^{*}$ & $0.132 \pm 0.003$ & $0.123 \pm 0.008 \dagger$ \\
\hline$n$ & 14 & 13 & 14 & 14 & 14 & 14 \\
\hline $\mathrm{P}_{18} \mathrm{X}$ & $0.149 \pm 0.003$ & $0.145 \pm 0.007$ & $0.173 \pm 0.007$ & $0.163 \pm 0.007 \dagger$ & $0.134 \pm 0.004$ & $0.124 \pm 0.007^{*}$ \\
\hline$n$ & 13 & 12 & 13 & 12 & 13 & 12 \\
\hline $\mathrm{M}_{2} \mathrm{X}$ & $0.157 \pm 0.010$ & $0.148 \pm 0.008 \dagger$ & $0.175 \pm 0.006$ & $0.169 \pm 0.007 \ddagger$ & $0.136 \pm 0.006$ & $0.128 \pm 0.008 \dagger$ \\
\hline$n$ & 16 & 13 & 16 & 13 & 16 & 13 \\
\hline $\mathrm{M}_{4} \mathrm{X}$ & $0.148 \pm 0.006$ & $0.141 \pm 0.007 \ddagger$ & $0.174 \pm 0.006$ & $0.164 \pm 0.010 \dagger$ & $0.134 \pm 0.005$ & $0.125 \pm 0.006^{*}$ \\
\hline$n$ & 14 & 13 & 14 & 13 & 14 & 13 \\
\hline$P_{18} M_{2} X$ & $0.148 \pm 0.005$ & $0.137 \pm 0.004 \S$ & $0.172 \pm 0.008$ & $0.156 \pm 0.005 \S$ & $0.128 \pm 0.004$ & $0.116 \pm 0.006 \S$ \\
\hline$n$ & 17 & 19 & 17 & 19 & 17 & 19 \\
\hline \multicolumn{7}{|l|}{ Males } \\
\hline $\mathrm{X}$ & $0.157 \pm 0.005$ & $0.140 \pm 0.006 \S$ & $0.176 \pm 0.010$ & $0.165 \pm 0.008 \ddagger$ & $0.133 \pm 0.006$ & $0.121 \pm 0.006^{*}$ \\
\hline$n$ & 13 & 10 & 13 & 10 & 13 & 10 \\
\hline$P_{18} X$ & $0.153 \pm 0.004$ & $0.149 \pm 0.009$ & $0.174 \pm 0.006$ & $0.169 \pm 0.007$ & $0.139 \pm 0.009$ & $0.123 \pm 0.003 \S$ \\
\hline$n$ & 12 & 12 & 12 & 12 & 12 & 12 \\
\hline $\mathbf{M}_{2} \mathbf{X}$ & $0.163 \pm 0.004$ & $0.156 \pm 0.010 \ddagger$ & $0.180 \pm 0.007$ & $0.175 \pm 0.011$ & $0.138 \pm 0.007$ & $0.128 \pm 0.012 \ddagger$ \\
\hline$n$ & 13 & 17 & 13 & 17 & 13 & 17 \\
\hline$M_{4} X$ & $0.155 \pm 0.006$ & $0.146 \pm 0.010$ & $0.179 \pm 0.004$ & $0.173 \pm 0.011$ & $0.135 \pm 0.006$ & $0.120 \pm 0.010^{*}$ \\
\hline$n$ & 12 & 12 & 12 & 12 & 12 & 12 \\
\hline $\mathbf{P}_{18} \mathbf{M}_{2} \mathrm{X}$ & $0.156 \pm 0.004$ & $0.140 \pm 0.009^{*}$ & $0.176 \pm 0.005$ & $0.160 \pm 0.007^{*}$ & $0.135 \pm 0.004$ & $0.120 \pm 0.009 *$ \\
\hline$n$ & 13 & 13 & 13 & 13 & 13 & 13 \\
\hline
\end{tabular}

$* p \leq 0.001$; Mann-Whitney test.

$+p \leq 0.01$; Mann-Whitney test.

$\ddagger p \leq 0.05$; Mann-Whitney test (not considered statistically significant).

$\S p \leq 0.0001$; Mann-Whitney test.

suppressed the growth rate after dosing, but compensatory growth returned body weight to control levels by $\mathrm{d} 80$, with female weights returning sooner than male weights.

These results indicate that growth is affected primarily by exposures involving cranial irradiation. Although effects on growth centered around cranial irradiation, these effects were not equal in all $\mathrm{X}$ exposure groups. Percent weight reduction varied among the $\mathrm{X}$ exposure groups (Fig. 3), as did significant changes in body and craniofacial proportions (Table 4). Radiation exposures tended to stunt body weight more than length, resulting in long bodies relative to weight (i.e. increased body length/weight ratio in Table 5). Cranial length was shortened by all $\mathrm{X}$ exposures 
MALES

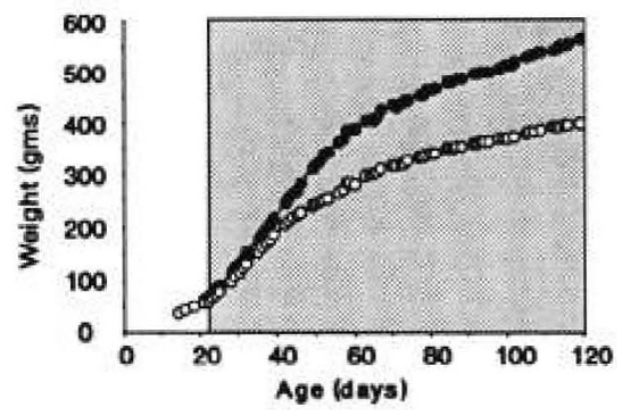

FEMALES

$\mathbf{x}$

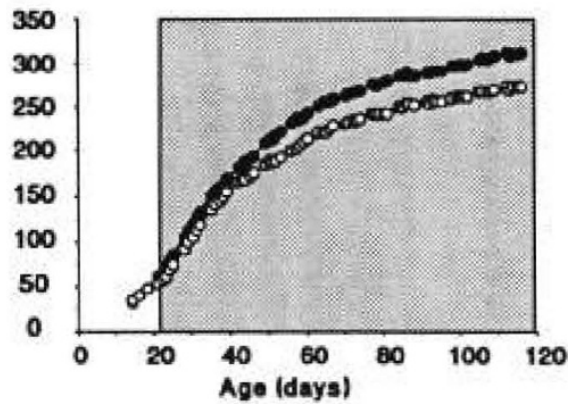

$\mathrm{M}_{2} \mathrm{X}$
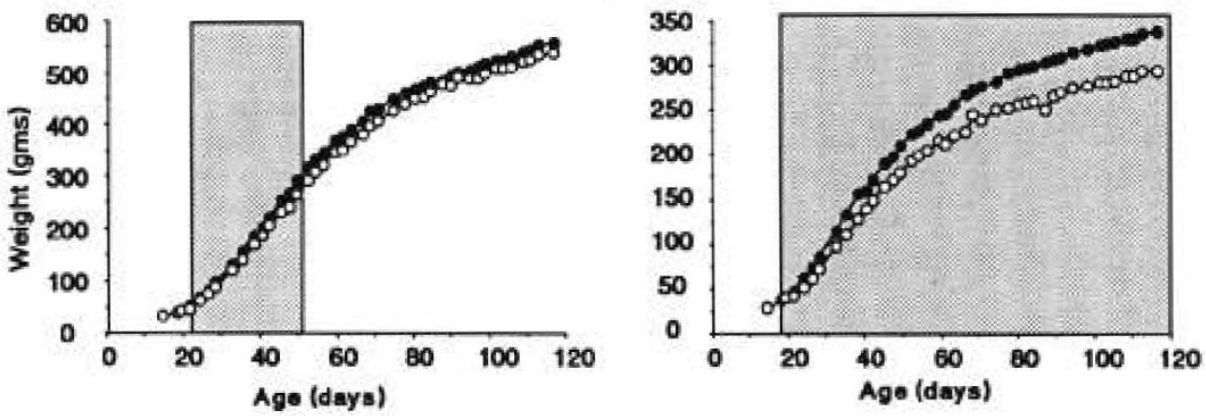

$P_{18} M_{2} X$
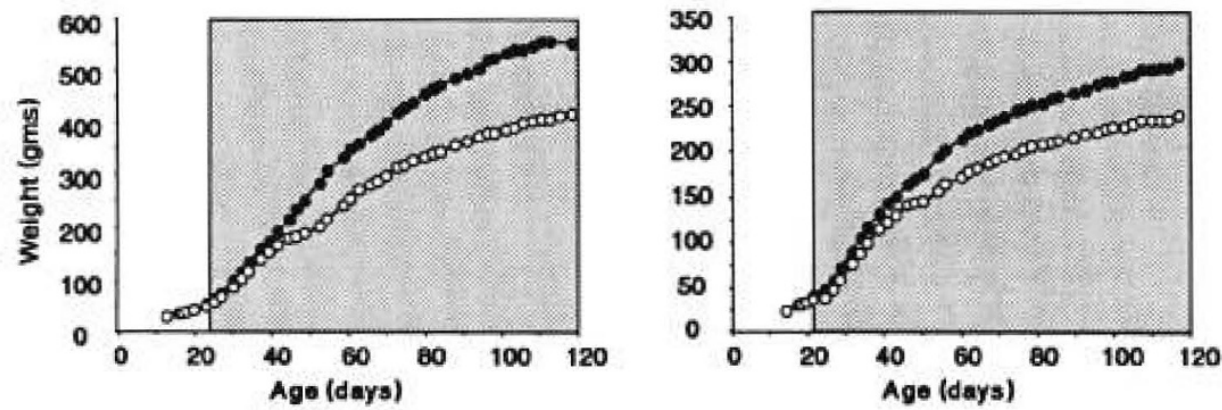

Fig. 4. Growth curves after exposure to $\mathrm{X}, \mathrm{M}_{2} \mathrm{X}$, and $\mathrm{P}_{18} \mathrm{M}_{2} \mathrm{X}$. $\bullet$, controls; $\mathrm{O}$, exposed. Shaded areas represent ages at which weights were significantly reduced from control levels. Female rats had permanently stunted growth from all three exposures. $\mathrm{M}_{2}$ protected the male rats from permanent growth stunting induced by $X$ alone except when prednisolone was added to the $M_{2} X$ exposure. $X$ and $P_{18} M_{2} X$ growth curves were previously presented in Schunior et al. (18).

(data not shown). Certain craniofacial proportions were altered consistently whether exposure was $\mathrm{X}$ alone or $\mathrm{X}$ combined with other exposures; basioccipital, sphenoid, and supraoccipital height tended to be reduced relative to cranial length (Table 6). Occipital height ratios demonstrated similar reductions after all $\mathrm{X}$ exposures (data not shown). In contrast to these similarities, ratios of femoral length to body length tended to increase with $X$ and $P_{18} M_{2} X(18)$, but they were generally unaffected by the other X combinations (Table 4). Whereas X alone allowed for some head sparing (body length shortened more than cranial length) (18), $\mathrm{X}$ combinations reduced cranial length in proportion to body length (see cranial length/body length in Table 5). Similarly, not all $\mathrm{X}$ combinations proportionally increased occipital width and transfrontal minimum width in females as $\mathrm{X}$ alone did in our earlier study (18) (Table 4). The $\mathrm{M}_{2} \mathrm{X}$ combination in males resulted in more normalized craniofacial proportions, different from the $\mathrm{X}$ pattern of craniofacial distortion. Because some effects varied among the $X$ exposure groups while the dose of radiation remained the same, the drugs preceding the radiation apparently modified the radiation response. This modification tended to be a protective effect; examples of the best protection occurred in $\mathrm{M}_{2} \mathrm{X}$ males and examples of the least protection in $\mathrm{P}_{18} \mathrm{M}_{2} \mathrm{X}$ males and females (Fig. 3; Tables 3 and 4).

Although prednisolone and methotrexate did not permanently reduce body weight in either sex, their modification of radiationinduced weight reduction was often dramatic (Fig. 4). The severe weight reduction caused by $X$ alone was mitigated by $M_{2} X$, resulting in the male rats reaching control weight levels by $\mathrm{d} 52$. However, the addition of prednisolone to this combination $\left(\mathrm{P}_{18} \mathrm{M}_{2} \mathrm{X}\right)$ resulted in a loss of protection and returned the males to the X pattern of permanent weight loss. A higher dose of methotrexate $\left(\mathrm{M}_{4} \mathrm{X}\right)$ before the radiation also led to a loss of this protection (Fig. 3). The protection did not occur with either $\mathbf{M}_{2} \mathrm{X}$ or $\mathrm{M}_{4} \mathrm{X}$ in the females (Figs. 3 and 4). Therefore, the modifying effects of methotrexate and prednisolone seemed dose, sex, and drug combination dependent. 
Table 7. Coincidence of growth and behavioral deficits*

\begin{tabular}{|c|c|c|c|c|}
\hline & \multicolumn{2}{|c|}{ Females } & \multicolumn{2}{|c|}{ Males } \\
\hline & Behavior & Growth & Behavior & Growth \\
\hline $\begin{array}{l}\mathbf{P}_{18} \\
\mathbf{P}_{36} \\
\mathbf{M}_{2} \\
\mathbf{M}_{4}\end{array}$ & & & + & \\
\hline $\begin{array}{l}X \\
P_{18} M_{2} \\
P_{36} M_{1}\end{array}$ & + & + & & + \\
\hline $\begin{array}{l}P_{18} X \\
M_{2} X\end{array}$ & $\begin{array}{l}+ \\
+\end{array}$ & $\begin{array}{l}+ \\
+\end{array}$ & + & + \\
\hline $\begin{array}{l}M_{4} X \\
P_{18} M_{2} X\end{array}$ & + & $\begin{array}{l}+ \\
+\end{array}$ & $\begin{array}{l}+ \\
+\end{array}$ & $\begin{array}{l}+ \\
+\end{array}$ \\
\hline
\end{tabular}

* Indicates significant $(p<0.01)$ change. Behavior $=$ significant RS values at 6 wk or $4 \mathrm{mo}$. See Mullenix et al. (19). Growth = significant reduction in body weight at $150 \mathrm{~d}$.

\section{DISCUSSION}

Cranial irradiation was responsible for a severely depressed growth trajectory not ameliorated by catch-up growth. It altered craniofacial proportions primarily posterior and ventral to the brain case. Prednisolone and methotrexate modified the growth response to cranial irradiation, despite their causing only shortterm growth deficits and rare changes in body and craniofacial proportions on their own. The pattern of radiation stunting was best prevented when methotrexate preceded cranial irradiation $\left(\mathrm{M}_{2} \mathrm{X}\right)$ in male rats. The $\mathrm{M}_{2} \mathrm{X}$ males recovered from a short-term growth deficit to attain adult control weight and length. Increasing the methotrexate dose within the combination $\left(M_{2} X\right.$ to $\left.M_{4} X\right)$ or adding prednisolone $\left(\mathrm{M}_{2} \mathrm{X}\right.$ to $\left.\mathrm{P}_{18} \mathrm{M}_{2} \mathrm{X}\right)$ led to the loss of protection in these males, returning the radiation pattern of stunted growth. Thus, similar to effects on behavior (19), effects on growth varied with dose, sex, and agent interactions.

Table 7 summarizes the growth-behavior relationship for all exposure groups. It shows that when treatment involved only cranial irradiation, growth deficits alone occurred. When treatment involved cranial irradiation combined with prednisolone, methotrexate, or both, growth and behavioral deficits coincided except for $M_{2} X$ in males and $P_{18} M_{2} X$ in females. $P_{18} M_{2} X$ in females prevented behavioral but not growth deficits, whereas $\mathbf{M}_{2} \mathbf{X}$ in males prevented both. These data suggest that, when attention is paid to dose, sex, and agent interactions, a combination can be selected that protects against both growth and behavioral deficits.

Several studies in the literature provide insight as to the potential cause of the growth and behavioral deficits observed here. The severe effect of cranial irradiation on catch-up growth in rats has been attributed to two defects: a disrupted link between catch-up growth control and growth hormone secretion, and a maladjustment of the central control for body size (22-24). Highdose glucocorticoid treatment also has been reported to reset target body size (25). This central control of body size may be located in the dorsomedial hypothalamic nuclei $(20,26,27)$. Bilateral lesions of dorsomedial hypothalamic nuclei in rats stunt growth and produce growth curves similar to those in rats neonatally exposed to just cranial irradiation (20). Moreover, the coincidence of growth and behavioral deficits when cranial irradiation, methotrexate, and prednisolone interact suggests involvement of hypothalamic neuropeptides. GRF and somatostatin affect both growth and behavior. The control of GRF and somatostatin over growth hormone secretory pattern has been well established $(28,29)$, and hyperactivity in response to GRF and hypoactivity in response to somatostatin have been reported (30). Other brain areas besides the hypothalamus cannot be ignored, however, inasmuch as bilateral lesions of the median raphe, ventrolateral thalamus, substantia nigra, and globus pallidus also stunt growth as well as impair learning $(20,31)$. Thus, various brain regions including the hypothalamus, hypothalamic neuropeptides, and growth hormone secretion should be evaluated in future studies of the cause of neurotoxicity by CNS therapy in animals.

The agent combinations examined here in rats are simpler than those used in the treatment of childhood ALL, where many chemotherapeutic agents are used, further increasing potential for agent interactions. Despite this difficulty, there are indications that our findings in animals might relate to the clinical situation. Clinical studies usually attribute effects on growth and craniofacial development to cranial irradiation $(5,9-11)$, although corticosteroids and chemotherapy are thought to be contributory $(1,32,33)$. Clearly, it is not understood how radiation schedules and chemotherapy protocols interact to cause growth failure and growth hormone deficiency $(3,34)$. The growth hormone requirements of children treated for ALL are still controversial (12). Studies of growth hormone responses in both monkeys (35) and humans (36) have indicated that the hypothalamus is more sensitive than the pituitary to cranial irradiation. Therefore, hypothalamic GRF might be important to children with radiation-induced growth hormone deficiency, as has been suggested by some investigators $(12,34)$. Clinical studies, similar to studies in animals, find both growth and behavioral effects associated with hypothalamic neuropeptides; GRF and somatostatin have been shown to improve mental performance by modifying attention and memory function (37-39). Abnormal growth hormone responses to GRF were found in prepubertal children with attention-deficit hyperactivity (40).

These parallels between clinical and animal observations warrant additional study of the potential for "optimal" combinations of CNS therapy agents. These combinations must protect against both growth and behavioral deficits without compromising efficacy. As this study indicates, consideration of dose, sex, and agent interactions would be critical to any such investigation.

Acknowledgment. The authors thank Amy Szeto for her technical assistance.

\section{REFERENCES}

1. Marky I, Samuelsson BO, Mellander L, Karlberg J 1991 Longitudinal growth in children with non-Hodgkin's lymphoma and children with acute lymphoblastic leukemia: comparison between unirradiated and irradiated patients. Med Pediatr Oncol 19:96-99

2. Schriock EA, Schell MJ, Carter M, Hustu O, Ochs JJ 1991 Abnormal growth patterns and adult short stature in 115 long-term survivors of childhood leukemia. J Clin Oncol 9:400-405

3. Kirk JA, Raghupathy P, Stevens MM, Cowell CT, Menser MA, Bergin M, Tink A 1987 Growth failure, growth-hormone deficiency after treatment for acute lymphoblastic leukaemia. Lancet 1:190-193

4. Clayton PE, Shalet SM, Morris-Jones PH, Price DA 1988 Growth in children treated for acute lymphoblastic leukaemia. Lancet 1:460-462

5. Sonis AL, Tarbell N, Valachovic RW, Gelber R, Schwenn M, Sallan S 1990 Dentofacial development in long-term survivors of acute lymphoblastic leukemia. Cancer 66:2645-2652

6. Brouwers P, Riccardi R, Fedio P, Poplack DG 1985 Long-term neuropsychologic sequelae of childhood leukemia: correlation with CT brain scan abnormalities. J Pediatr 106:723-728

7. Waber DP, Urion DK, Tarbell NJ, Sollee ND, Dinklage D, Giola G, Paccia J 1990 Late effects of central nervous system treatment of childhood acute lymphoblastic leukemia are sex-dependent. Dev Med Child Neurol 32:238248

8. Waber DP, Tarbell NJ, Kahn CM, Gelber RD, Sallan SE 1992 The relationship of sex and treatment modality to neuropsychological outcome in childhood acute lymphoblastic leukemia. J Clin Oncol 10:810-817

9. Dowell RE, Copeland DR, Francis DJ, Fletcher JM, Stovall M 1991 Absence of synergistic effects of CNS treatments on neuropsychologic test performance among children. J Clin Oncol 9:1029-1036

10. Wells RJ, Foster MB, D'Ercole J, McMillan CW 1983 The impact of cranial irradiation on the growth of children with acute lymphocytic leukemia. Am J Dis Child 137:37-39

11. Uruena M, Stanhope R, Chessells JM, Leiper AD 1991 Impaired pubertal growth in acute lymphoblastic leukaemia. Arch Dis Child 66:1403-1407

12. Shalet SM, Clayton PE, Price DA 1988 Growth and pituitary function in children treated for brain tumours or acute lymphoblastic leukaemia. Horm Res 30:53-61

13. Mulhern RK, Wasserman AL, Fairclough D, Ochs J 1988 Memory function in disease-free survivors of childhood acute lymphocytic leukemia given CNS 
prophylaxis with or without 1,800 cGy cranial irradiation. J Clin Oncol 6:315-320

14. Bleyer WA 1988 Central nervous system leukemia. Pediatr Clin North Am 35:789-814

15. Billett AL, Gelber RD, Tarbell NJ, Barr R, Blattner S, Clavell L, LeClerc JM, Lipton J, Schwenn M, Schorin M, Cohen HJ, Sallan S 1993 Sex differences in the risk of central nervous system (CNS) relapse in childhood acute lymphoblastic leukemia (ALL). Proc Am Soc Clin Oncol 12:317(abstr 1045)

16. Balsom WR, Bleyer WA, Robinson LL, Heye RM, Meadows AT, Satarz A, Blatt J 1991 Intellectual function in long-term survivors of childhood acute lymphoblastic leukemia: protective effect of pre-irradiation methotrexate? A Childrens Cancer Study Group study. Med Pediatr Oncol 19:486-492

17. Mullenix PJ, Kernan WJ, Tassinari MS, Schunior A, Waber DP, Howes A, Tarbell NJ 1990 An animal model to study toxicity of central nervous system therapy for childhood acute lymphoblastic leukemia: effects on behavior. Cancer Res 50:6461-6465

18. Schunior A, Zengel AE, Mullenix PJ, Tarbell NJ, Howes A, Tassinari MS 1990 An animal model to study toxicity of central nervous system therapy for childhood acute lymphoblastic leukemia: effects on growth and craniofacial proportion. Cancer Res 50:6455-6460

19. Mullenix PJ, Kernan WJ, Schunior A, Howes A, Waber DP, Sallan SE, Tarbell NJ 1994 Interactions of steroid, methotrexate and radiation determine neurotoxicity in an animal model to study therapy for childhood leukemia. Pediatr Res 35:171-178

20. Mosier HD, Jansons RA, Thompson R, Crinella FM, Yu J 1990 Production of generalized learning deficit and permanent growth stunting by bilatera brain stem lesions. Pediatr Res 27:181-185

21. Appleton RE, Farrell K, Zaide J, Rogers P 1990 Decline in head growth and cognitive impairment in survivors of acute lymphoblastic leukaemia. Arch Dis Child 65:530-534

22. Mosier HD 1988 Growth failure in the head-irradiated rat. Horm Res 30:7783

23. Mosier HD, Jansons RA, Swingle KF, Dearden LC 1986 Dissociation of catchup growth control and neural control of growth hormone secretion in the stunted head-irradiated rat. Pediatr Res 20:261-264

24. Mosier HD, Jansons RA, Swingle KF, Sondhaus CA, Dearden LC, Halsall LC 1985 Growth hormone secretion in the stunted head-irradiated rat. Pediatr Res 19:543-548

25. Mosier HD, Jansons RA 1989 Rats stunted by high-dose glucocorticoid treatment are capable of undergoing catch-up growth after fasting. Pediatr Res 25:373-376

26. Van den Pol AN 1982 Lateral hypothalamic damage and body weight regula- tion: role of gender, diet, and lesion placement. Am J Physiol 242:R265R274

27. Bernardis LL, Tannenbaum GS 1987 Failure to demonstrate disruption of ultradian growth hormone rhythm and insulin secretion by dorsomedial hypothalamic nucleus lesions that cause reduced body weight, linear growth and food intake. Exp Brain Res 66:572-576

28. Painson J-C, Tannenbaum GS 1991 Sexual dimorphism of somatostatin and growth hormone-releasing factor signaling in the control of pulsatile growth hormone secretion in the rat. Endocrinology 128:2858-2866

29. Argente J, Chowen JA, Zeitler P, Clifton DK, Steiner RA 1991 Sexual dimorphism of growth hormone-releasing hormone and somatostatin gene expression in the hypothalamus of the rat during development. Endocrinology 128:2369-2375

30. Cacabelos R, Niigawa H, Alvarez XA, Munoz MD, Nishimura T, Rubia FJ 1990 Antagonistic effects of growth hormone-releasing factor (GRF) and somatostatin on locomotor activity: GRF-induced hyperkinetic syndrome. Meth Find Exp Clin Pharmacol 12:425-434

31. Thompson R, Huestis PW, Crinella FM, Yu J 1986 The neuroanatomy of mental retardation in the white rat. Neurosci Biobehav Rev 10:317-338

32. Tamminga RYJ, Kamps WA, Drayer NM, Humphrey GB 1992 Longitudinal anthropometric study in children with acute lymphoblastic leukaemia. Acta Paediatr 81:61-65

33. Marky I, Mellander L, Lannering B, Albertsson-Wikland K 1991 A longitudinal study of growth and growth hormone secretion in children during treatment for acute lymphoblastic leukemia. Med Pediatr Oncol 19:258-264

34. Shalet $\mathrm{S} 1988$ Growth and development in children treated for cancer. Genera discussion. Horm Res 30:90-91

35. Chrousos GP, Poplack D, Brown T, O'Neill D, Schwade J, Bercu BB 1982 Effects of cranial radiation on hypothalamic-adenohypophyseal function: abnormal growth hormone secretory dynamics. J Clin Endocrinol Metabol 54:1135-1139

36. Blatt J, Bercu BB, Gillin JC, Mendelson WB, Poplack DG 1984 Reduced pulsatile growth hormone secretion in children after therapy for acute lymphoblastic leukemia. J Pediatr 104:182-186

37. Alvarez XA, Cacabelos R 1990 Effects of GRF (1-29) $\mathrm{NH}_{2}$ on short-term memory: neuroendocrine and neuropsychological assessment in healthy young subjects. Meth Find Exp Clin Pharmacol 12:493-499

38. Cacabelos $\mathbf{R} 1989$ Growth hormone-releasing factor in mental disorders: a diagnostic marker and therapeutic alternative. Meth Find Exp Clin Pharmacol 11:421-436

39. Cacabelos $\mathbf{R} 1989$ Growth hormone-releasing factor in mental disorders. Drug News Perspect 2:133-140

40. Cacabelos R, Albarran M, Dieguez C, Farinas F, del Pina JL, Exposito J, Marin-Leoches M 1990 GRF-induced GH response in attention-defici hyperactivity disorder. Meth Find Exp Clin Pharmacol 12:79-85 